\title{
十解 説十
}

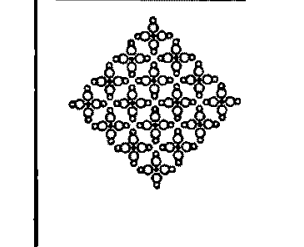

\section{原子カ基盤技術開発とクロスオーバー研究}

\author{
21 世紀に向けて
}

（科学技術㕂原子力局）國 谷 実

本稿は、21世紀に向けて原子力技得にブレークスルーをるたらすために科学技街庁が推進している原子 力基盤技街開発を包括的に説明したすのである。原子力基盤技訹開発を推進するに至った背景や技術開発

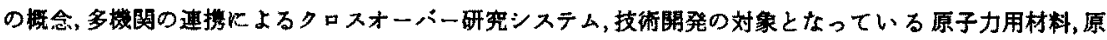
子力用人工知能, 原子力用レーザー，放射線りスク評価・低娍化の 4 技街領域の内容を概説した。

1.はしめに

これまで科学技術庁が主導してきた我が国の原子力 開発利用を振り返ってみると，原子力発電等を早期に 実用化することを目指しながら，初期段階では欧米の 進んた技術を導入することによりこれに追いつき，さ らに高速妒などの新型妒や核然料サイクル技術におけ る欧米の技術に目標を固いた自主開発を進めてきた。 この結果，今日では原子力哞電が定着するととるに， 核然料サイクルが事業化段階に達する等, 原子力技術 の実用化は着実に進展している。しかしながらこれ までの技術開発の性格は既存の技術を組み上け゚ていく ブロシェクト型が中心であり，また技術受入れに重点 を直いたいわゆる゙キャッチフップ型”であったため， 技術革新を自ら積極的に生み出すとい5。のではなか った。原子力は今後とすエネルギーセキュリティを碓 保する上で重要な役割を果たするのであるが，すでに 原子カのリーディングカントリーに発展した我が国と しては，新しい原子力技術や知識を創出することによ って世界の発展に真献していく役割を担らことが従来 以上に求められている。このような時代環境の変化を 踏まえてこれに対処していくために，原子力委員会で は「原子力開発利用長期計画」(以下，「長計」)を昭和62 年6月に策定した。「長計」は，原子力の研究，開発およ び利用に関する指針の大桐と基本的な施策の推進方策 を示したるので，特に，科学技衍全般への波及奻果が 期待される創造的・革新的技術開発を重視している。 かかる技術開発を担らのが，以下に述べる原子力基盤 技衍開発である。

\section{II. 原子力基盤技術開発の概念}

「長計」では，原子力基盤技術を「原子力の各分野にわ たる中長期的な二ースを踏をえ，これに靺力的に対応 し，かつ新しい技術を㓣出し，ひいては原子力技衙体 系のフレークスルーを引き起こす可能性のある技就」 と捉えている。すなかち，既存技術の組合せではな く，中長期的観点火立って原子力のいろいるな分野に 応用可能な創造的・革新的技術で，しかる得られる咸 果が既存技術にブレークスルーをるたらし，一般の科 学技術分野への波及效果も期待できる基盤的な技術を いっている。原子力基盤技術開発は，基礎研究とブロ ジェクト研究の中間に位置し、今後の原子力政策の大 きな柱の一つになっている。開発すべき原子力基盤伎 術領域としては,

(1) 原子力用材料

(2) 原子力用人工知能

(3) 原子力用レーザー

(4) 放射線リスク評価・低減化

の4 領域が取り上げられている。各領城の開発内容は 後述するが，第 1 図に原子力基盤技術とその応用の展 開図を，第1表に技術体系を示す。なお，現在は 4 㴭 域が取り上げられているが，適宜新たな技術領域の追 加を検討することになっている。

具体的な技衍開発推進方策については，原子力委員

Nuclear Underlying Technology Development and Cross-Over Research, In facing the 21st century: Minoru KUNIYA.

（1989年 12月21日 受理） 
第 2 露原子力基然技術開発の平成 2 年度予算钼

（）内仕，元年度予笨禎（単位：100万円）

\begin{tabular}{|c|c|c|c|c|c|}
\hline 項目領 城 & 材 料 & 人工知㼄 & レーザー & 放射線リスク & 粉計 \\
\hline 基盤全体 & $874(783)$ & $\begin{array}{l}927 \\
674(481)\end{array}$ & $\begin{array}{r}525(247) \\
674(497)\end{array}$ & $442(290)$ & $\begin{array}{l}(11,452(247) \\
2,676(2,063)\end{array}$ \\
\hline 了ち，クロスオーバー研究 & 182(113) & $183(142)$ & $\begin{array}{r}525(247) \\
421(149)\end{array}$ & $119(81)$ & $\begin{array}{r}525(247) \\
905(485)\end{array}$ \\
\hline 3ち, テータフリーウェイ研究 & $65(0)$ & - & - & - & $65(0)$ \\
\hline
\end{tabular}

テムは，「研究推進委員会」および 4 技衍領域それぞれ に対応した 4 つの「研究交流委員会」から構成されてい 万(第 2 図)。研究推進委員会は参加機関の代表者，座. 学・官からの有識者より構成され(委員長岋藤家洋一東 工大教投 原子如工学研究所長)，研究の基本方針の策 定等を審議・愉討している。研究交流委員会は参加機 関の研究実施者㧍よび有識者より構成され，研究の具 体的な推進のために必要な技術的事項等を検討してい る。なお「「クロスオーパー研究」を説明したパンフレッ トが研究推進委員会より出ているので参照されたい。
研究開発は，現在とりあえず 4 技術領域それそれに 1 つずつ研究課題を設け(第 3 表)，第 1 期 5 年間(平 成元年度〜 5 年度)の予定で開始されたが，さらに推 進するために，本研究への参加，共同研究等の申入れ を産·学·官の多方面に現在呼びかけているところであ る。「クロスオー・ー研究」の研究体制，その他全体的 な事項についての問合せは科学技術㕂原子力局技街振 興課で，各技術領域の具体的内容についての問合せは 第 3 表に示した各幹事機関の企画室で行っており，関 係各位の積極的参加を期待している。

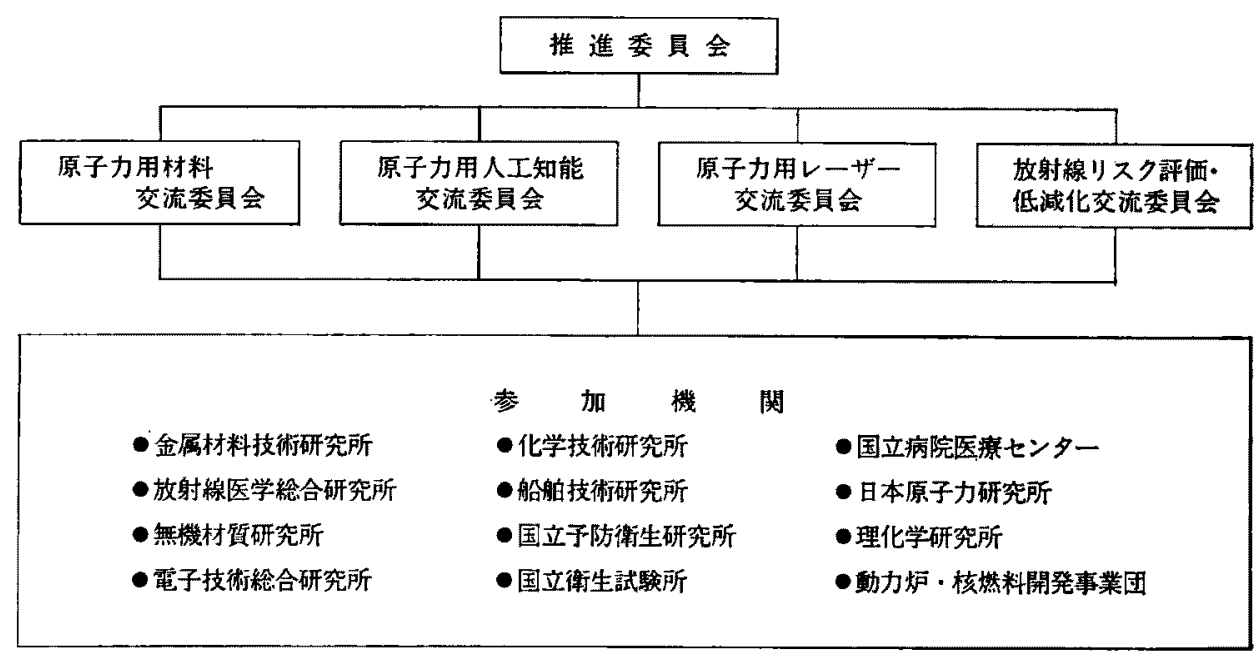

第 2 图「クロスオーパー研究」システムの楼成図

\section{IV. 各技術領域の開哞内容}

\section{1. 原子力用材料}

材料技術の特彺は，あらゆる科学技術において鍵と なると同時に，開発された技術が他の分野の技術革新 を誘発するといら波及奻果を有して扣り，この意味て はいかなる分野の材料技術当生来的に「基盤技術」とい える。

基盤技術開発では，最新の新素材技術の動向に留意
しつつ，高性能化・高機能化を狙った全く新しいタイ プの材料創製，放射線環境下で起こる諸現象のミクロ レベルにおける機構解明・評価,信頼性·安全性技術の 高度化を行い，成果のデータベース化を目指してい る。特に「クロスオーバー研究」としては，原子力極限賟 境に特有な，照射によって加速される材料化学反応現 象を，金属系材料，七ラミックス系材料，高分子系材料 について，多様な角度から研究を行っている(第 3 図)。 
第 3 表「クロスオーハー研究」課題

\begin{tabular}{|c|c|c|c|c|}
\hline 技衍領城 & 原子力用材料 & 原子力用人工知能 & 原子カ用レーザー & $\begin{array}{l}\text { 放射線リスク } \\
\text { 評洒・低減化 }\end{array}$ \\
\hline 研究課題 & $\begin{array}{l}\text { 原子力柾限懪境材料の開 } \\
\text { 発に関する研究 }\end{array}$ & $\begin{array}{l}\text { 原子力用人工知能を具備 } \\
\text { した原子力施設のシステ } \\
\text { ム評価研究 }\end{array}$ & $\begin{array}{l}\text { 原子力用新レーザーの研 } \\
\text { 究開発（自由電子レーザ } \\
\text { 一） }\end{array}$ & $\begin{array}{l}\text { 放射線による染色体翼常 } \\
\text { の高速自動解析システム } \\
\text { に関する研究 }\end{array}$ \\
\hline 参加機関 & $\begin{array}{l}\text { 金属材料技術研究所 } \\
\text { 無機材所研究所 } \\
\text { 化学技術研究所 } \\
\text { O日本原子力研究所 } \\
\text { O功力枦·核橪料開発事 } \\
\text { 業団 }\end{array}$ & 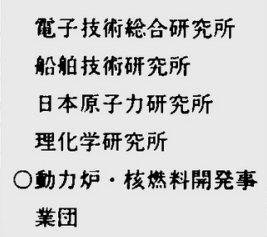 & $\begin{array}{l}\text { 䉓子技術棯合研究所 } \\
\text { O日本原子力研究所 } \\
\text { 理化学研究所 } \\
\text { 動力炬 · 核替料開発事 } \\
\text { 業団 }\end{array}$ & 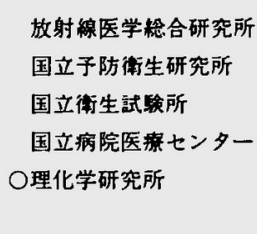 \\
\hline
\end{tabular}

O印 幹事機関

\section{2. 原子カ用人工知能}

原子力施設は一般産業の施設と比較して大規模かつ 複雑であり，作業の内容が極めて多様であることなら びに放射性物質を取り扱う施設であること等の特殊性 を有することから，原子力用人工知能技術は一般産業 における人工知能技術に比へ高度な信頼性を持つ必要 があること等箶しい要求が課せられていることを十分 に認識して技術開発を進める必要がある。

基椠技術開発では，コンピュータサイエンスや情報 処理技術の急速な進歩に留意しつつ，人間の運転・保 守等を支援する点検・補修用ロボットやマン・マシン・ インタフェースの良い運転監視システムを伴った人間 支援型プラントから,究極的には自己判断・制御を行 自律型ブラントを目指している。特に「クロスオーハ 一研究」としては, 自律型ブラントに向けて, システム の概念を明らかにするとともに，知識べース等の要素 技術のブラントへの適応性を評価している(第 4 図)。

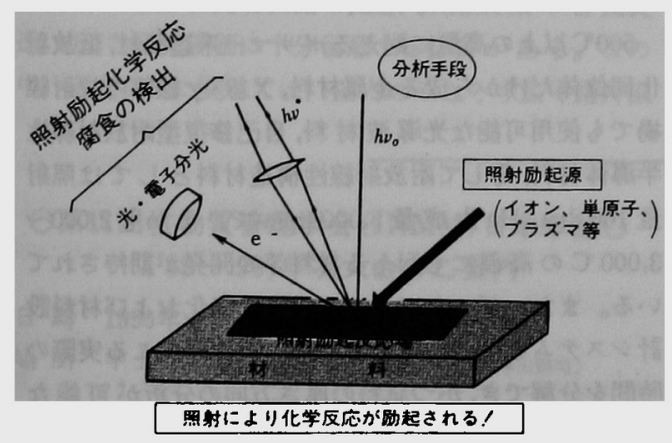

第 3 図照射により励起される化学反忘の追跡

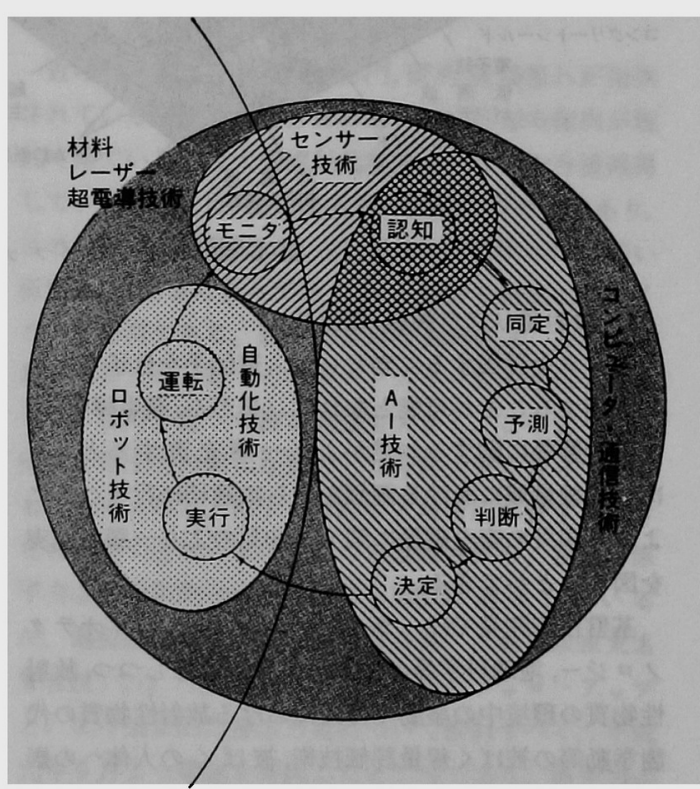

第 4 图自律ブラントに向けた技術開発分野

3. 原子カ用レーザー

レーザーは，時間的・空間的制御性の極めて良い光 の利用を可能とするが，これらの性質を原子力分野に 利用するに当たっては，高密度なエネルギーとしての 特性はもとより，例えば同位体分離技術においては大 量処理, 経済性が必要となるなど基本的に高出力が要 求される。

基盤技術開発では，最新の光技術やエレクトロニク ス技術等に留意しつつ, 同位体・元素等の分離技術, レ 
ーザー計測・分析技術, レーザー加工技術等, 原子力分 野へのレーザー応用技術, 高出力, 波長可変, 高効率等 のレーザー本体技術, そして原子力に新たな利用の可 能性を与えるレーザー物理・化学利用技術の開発を目
指している。特に「クロスオーハー研究」としては, 従 来の発振方法とは全く異なる，加速器を使った波長か 連続可変で大出力発振が可能な自由電子レーザーを研 究開発している(第 5 図)。

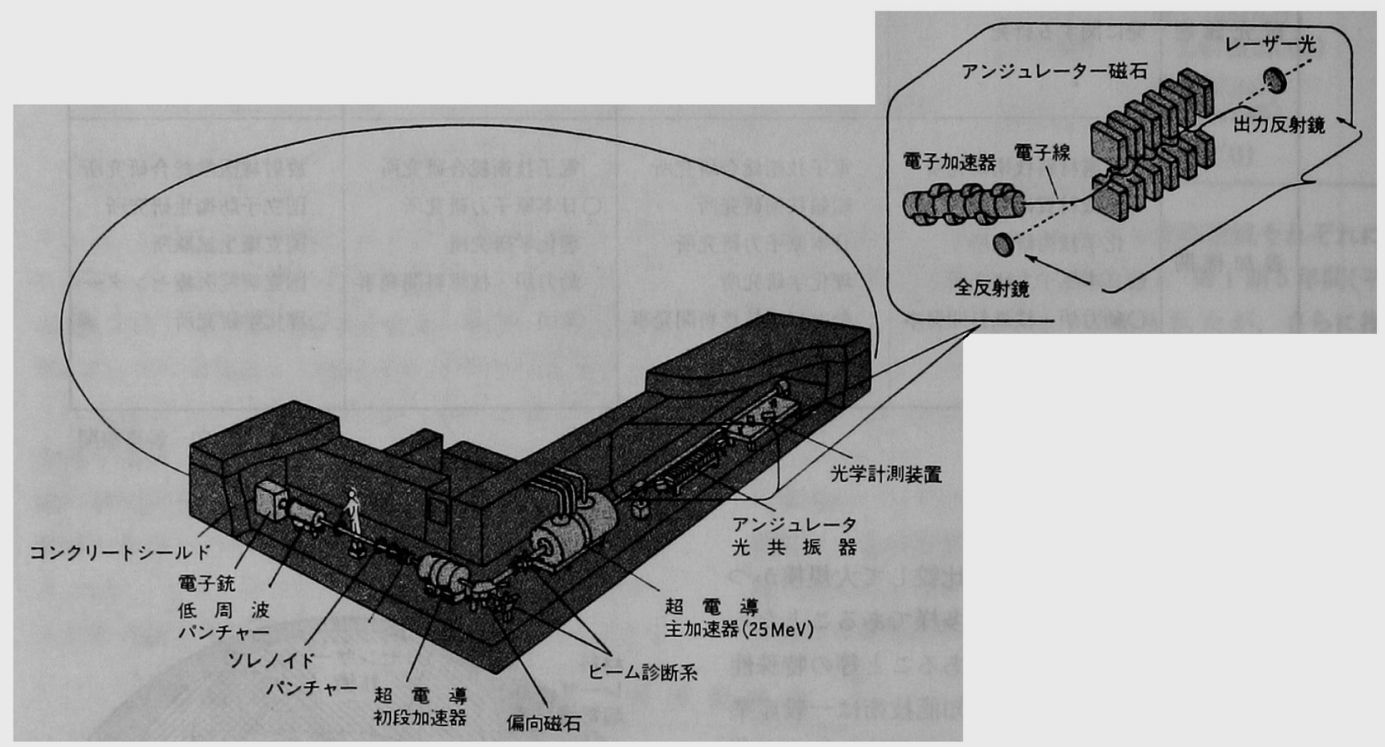

第 5 図 超電尊ライナックによる自由電子レーザー

\section{4. 放射楾リスク評価・低減化}

リスクを評価するに当たって，遗伝子を分子レベル で評価することが可能となれば，発がん，発生障害, 遣 云的影䈉等に関する知見がより一層充実するととも に，低線量域における評価をさらに適切に行うことに より，国民の安全確保に関する知見のより一層の充実 を図ることができる。

基盤技術開発では, ライフサイェンス,ハイオテク ，ロジー,地球科学等の最新の成果に留意しつつ, 放射 性物質の環境中の挙動や体内における放射性物質の代 謝挙動等の被ばく線量評価技術, 被ばくの人体への影 喓評価技術，そしてこれらの知見をもとにリスクを低 减化する技術の開発を目指している。特に「クロスオ 一ハー研究」としては, 従来困難であった低線量のリス ク評価の高度化を目指して, 放射線による異常染色体 の検出・解析を高速自動化するシステムを研究開発し ている(第 6 図)。

\section{V. 原子力基盤技術開発の将来像}

今後の技術開発の明確な実現目標を正確に設定する ことは容易ではないが，21世紀を見越した数10年間に わたる長期的な開発イメージを以下に示す。

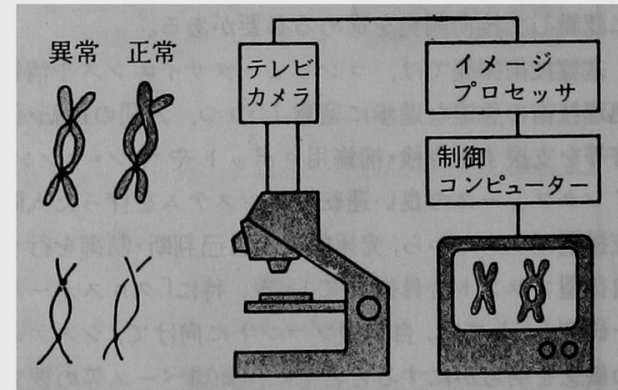

第 6 図染色体異常の高速自動解析システム

\section{1. 原子力用材料の将来像}

$500^{\circ} \mathrm{C}$ 以上の高温に耐えるポリマー系遮蔽材，低放射 化同位体だけから成る金属材料，X線・ $\gamma$ 線等の放射線 場でも使用可能な光導波材料, 自己修復型耐放射線珄 半導体材料，そして耐放射線性構造材料としては照射 量 $100 \mathrm{dpa}, \mathrm{He}$ 生成量 5,000 ppmで, しかる2,000 3,000 Cの高温にも耐える材料等の開発が期待されて いる。また，データべースの人工知能化および材料設 計システムを開発するとともに，現象が起こる実際の 時間を分解でき,かつ試料の厚さ方向の分析が可能な 実時間 3 次元マイク口構造解析技術の確立が期待され ている。 


\section{2. 原子カ用人工知领の将来哄}

原子力用人工知能技術開発のテンボは，新型如や核 然料サイクルに関した技涌開発に比べて極めて早く進 むと予測されている。マン・マシン・インタフェース技 術を活用した運転監視システム, 知識ベース・システム の中核的技術である自律型基本形成システム，自律型 ロボットと自律型プラントの実現が期待されている。 さらに，超知能化コンピュータ・システムとバイオ・コ ンピュータ・システムならびにそれらを統合したコン ビュータ・システムが串現すれば，超自律型ロボット と㗉自律型ブラントの実現が期待される。

\section{3. 原子カ用レーザーの将来像}

原子力分野へのレーザー庆用技術開発とレーザー本 体技術開発は中期的ビションを持ち，また原子力に新 たな利用の可能性を与えるレーザー技術開発は長期戦 略的観点から推進していく必要がある。同位体・元素 等の分離技術ではクラムオーダーの分離が可能なシス テム䓅術,レーザー計湘・分析技術の原子力施設への1 ンライン化，レーザー加工技術の実用化段階への移行， レーザーブラズマ利用に関してはブラズマ制御等のシ ステム化技術の実現が期待されている。

\section{4. 放射線リスク評価・低娍化の将来像}

放射線りスク評価技術は，将来における遺公子レべ ルでの放射線影傩の理解に基づき，関連する物理・化 学および情報処理技術の先端技術の導入に上り，個人 および集団における健康りスクの総合的な評価を目指 すすのである。放射線リスク低減化技術については， 新しい低減化の概念が生み出されることが期待され 万。

\section{V. 原子力基盤技術開発の効率的推進}

原子力基盤技術開発の特改に鑑みた効率的推進を行 5に当だっては，研究交流促進の体制整備, 施設整備 之利用の促進, 研究者交流の促進, 研究成果の普及促 進,的確な研究評価に十分留意する必要がある。この 中，研究交流に関しては，国内のみならす広く諸外国
との共同研究,研究交流を進める上で必要となる刢造 的な人材の意識的な育成，さらに，得られる成果をデ 一タベース化し、それをリンク化するネットワーク機 能を棈極的に促進することに留意する必要がある。材 料データベースのネットワーク化については, 平成 2 年度に「基盤原子力材料データフリーウェイ構築に関 する研究」として発足する予定である。また, 研究成果 の普及促進に当たっては，成果を原子力分野のみなら ず一般の科学技術分野人普及させていくことや国噔シ ンホシシウムの皘極的開催に留意する必要がある。な 拉，この一謤として，原子力用レーザー技衍領域では 自由電子レーザーに関する国際シンボジウムを開催す ることになっている(自由電子レーザー東京国際シン ボシウム' 90 平成 2 年 1 月29 30日, 於虎/門バスト ラル)。

\section{ท.おわりに}

近年, 理工系学生の製造部門, 研究現場離れが指摘 されているが，原子力分野においても同棣の㑯向が現 れて来ている。巨大先端科学技術システムを今後䊒持 していくためには，優秀な人材の確保は不可欠であり， このためには成热期に入った原子力分野におけるる若い 研究者，技術者にとって蚛力ある分野を劍出していく ことが必要である。原子力基盤技術開発は，原子力に おける新たな分野でのプレークスルーをもたらすとと るに，他の分野への波及効果す大きく，このよ5な意 味でも原子力の新たな芽として今後大きく育っていく むのと考えられ，原子力分野の人材育成に資する大き な柱の一つとなっていくものと期待される。現在，原 子力基然技術開発は予算的にむ順調に進展している が，基盤技術推進専門部会(現会長; 三島良績東大名 誉教授)では，原子力基盤技術推進のフォローアッブ と，上り奻果的な推進方策について検討すへく，平成 元年 9 月より審議を再開したところである。原子力基 盤技術研究への参加を含め，産·学·官の各分野での幅 広い参加を期待するすのである。
O第11回核物算管理学会 (INMM) 日本本部O ('89 '90)年次大会のご案内

日年 1990 年 6 月 日(木) $9: 30 \sim 17: 30$ (予定)

堵 所学士会馆本館会議室(東京都千代田区神田鎧町)

1. 招待晥 (午前)一交涉中一 ○フログラム゚
・ソ連・東欧の情势について

2. 确究表·ボスターセッション・展示会(午後)

○加申远所定用紙飞記入の上5月25日（金）(定日 150名）

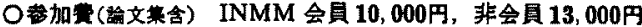

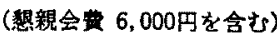

問合世·申込先 (广100)東京部千代田区办田町2-17-13 (斯)核物的管理せンター・企面空内 INMM 日本本部 亭确局(03-593-2551，FAX 03-593-2550) 